\title{
The effect of nitrous
} oxide on the oxyhaemoglobin dissociation curve

The influence of nitrous oxide on the oxyhaemoglobin dissociation curve (ODC) was studied using blood from twenty healthy patients. When the blood samples were exposed to 50 per cent $\mathrm{N}_{2} \mathrm{O}$ during the determination of the $O D C$, a left shift was observed and the $P_{s o}$ was decreased by $1.06 \mathrm{kPa}(8 \mathrm{mmHg})$. This shifi cannot be explained by temperature, $\mathrm{pH}, \mathrm{PCO}_{2}$, or 2.3-DPG effects. Following exposure of the blood to $\mathrm{N}_{2} \mathrm{O}$-free gases, the shift disappeared rapidly, and a normal $P_{s o}$ $(3.46 \mathrm{kPa})(26 \mathrm{mmH})$ was reobtained. In keeping with this reversibility, blood samples taken before and during 45 minutes of $\mathrm{N}_{2} \mathrm{O}$-curare anaesthesia showed identical dissociation curves to those which had been obtained during the in vitro $\mathrm{N}_{2} \mathrm{O}$ exposure experiment.

\section{Key words}

BLOOD: oxyhemoglobin dissociation, $\mathrm{P}_{50}$; ANAESTHETICS, GASES: nitrous oxide.

Nitrous oxide is probably the most popular anaesthetic agent used during general anaesthesia, even if it is not very potent. We use it because of its analgesic properties and because it was believed to be innocuous to the patient. Recently this innocuousness has been questioned. ${ }^{1-4}$ Furthermore, the presence of nitrous oxide in human blood interferes with polarographic $\mathrm{O}_{2}$ measurements ${ }^{5-6}$ and with the oxyhaemoglobin dissociation curve. ${ }^{7}$

With reference to the last two observations, we

From the Deparment of Anesthesiology, Laval University Hospital Center, Quebec, Que.

Address correspondence to: Louis Foumier MD, Department of Anesthesiology, Laval University Hospital Center, 2705 blvd Laurier, Qucbec, Que, G1V 4G2.

Paper presented in part at the annual meeting of the Canadian Society of Anesthesiologists, May 1982. noticed systematic discrepancies between the blood $\mathrm{PO}_{2}$ and oxygen saturation in patients receiving $\mathrm{N}_{2} \mathrm{O}$ anaesthesia, but not in patients who were in the intensive care unit, even after the usual corrections for temperature, $\mathrm{pH}$ and $\mathrm{PCO}_{2}$ had been made.

Such a discordance between blood $\mathrm{PO}_{2}$ and saturation can be explained in two ways. First, one of the readings can be wrong because of a technical error. Second, there might be a shift in the oxyhaemoglabin dissociation curve. We decided to examine these two possibilities in order to find the basis for the discrepancies noted in patients receiving nitrous oxide during general anaesthesia.

\section{Methods}

We selected 20 patients, ASA physical status 1 , who were to receive an $\mathrm{O}_{2}-\mathrm{N}_{2} \mathrm{O}$-curare anesthetic without any other inhalation agent.

Two venous blood samples were withdrawn from each patient: one prior to induction of anaesthesia and the other after 45-60 minutes of anaesthesia with $\mathrm{O}_{2}-\mathrm{N}_{2} \mathrm{O}$

For each sample we obtained two oxyhaemoglobin dissociation curves using an Hem-O-Scan ${ }^{\circ}$ analyzer (American Instrument Co., Silver Spring).

This instrument generates an $\mathrm{HbO}_{2}$ dissociation curve by equilibrating two microliters of blood with a gas mixture of controlled $\mathrm{PO}_{2}$. During analysis the $\mathrm{PO}_{2}$ in the mixture is increased within five minutes from 0 ta ca. $23.94 \mathrm{kPa}(180 \mathrm{mmHg}$ ) by automatically mixing an $\mathrm{O}_{2}$-free gas (zero gas) with a gas of known $\mathrm{O}_{2}$ (span gas). The $\mathrm{PO}_{2}$ in the equilibrating mixture is continuously monitored with a Clarktype oxygen electrode. The electrode, which has an Au cathode, is polarized at $0.78 \mathrm{~V}$. Standard $\mathrm{O}_{2}$ electrolyte (half saturated $\mathrm{KCl}$ at $\mathrm{pH} 5.9$ ) and Teflon membranes (Yellow Springs Instrument Co., Yellow Springs) were used. The $\mathrm{HbO}_{2}$ saturation of a blood sample tested in the Hem-O-Scan is 
TABLE I Data for $\mathrm{P}_{50} ; \mathrm{PCO}_{2} ; \mathrm{pH} ; 2,3-\mathrm{DPG}$

\begin{tabular}{|c|c|c|c|c|}
\hline \multirow[b]{2}{*}{$\mathrm{P}_{50}$, without $\mathrm{N}_{2} \mathrm{O}$ in the } & \multicolumn{2}{|l|}{ Pre-op } & \multicolumn{2}{|l|}{ Per-op } \\
\hline & $3.5 \pm 0.1 \mathrm{kPa}$ & $26.4 \pm 1.0 \mathrm{mmHg}$ & $25.9 \pm 1.5 \mathrm{mmHg}$ & $3.4 \pm 0.2 \mathrm{kPa}$ \\
\hline $\begin{array}{l}\mathrm{P}_{\mathrm{so}}, \text { with } 50 \% \text { in the } \\
\text { equilibrating gases }\end{array}$ & $2.4 \pm 0.2 \mathrm{kPa}$ & $18.4 \pm 1.4 \mathrm{mmHg}$ & $18.3 \pm 1.6 \mathrm{~mm} \cdot \mathrm{Hg}$ & $2.4 \pm 0.2 \mathrm{kPa}$ \\
\hline $\mathrm{PCO}_{2}$ & $5.1 \pm 0.5 \mathrm{kPa}$ & $38.6 \pm 4.1 \mathrm{mmHg}$ & $33.4 \pm 7.5 \mathrm{mmHg}$ & $4.4 \pm 1.0 \mathrm{kPa}$ \\
\hline $\begin{array}{l}\mathrm{pH} \\
2,3-\mathrm{DPG}(\mu \mathrm{mcl}-\mathrm{ml} \text { of blood) }\end{array}$ & & $\begin{array}{l} \pm 0.03 \\
\pm 0.33\end{array}$ & $\begin{array}{l}7.43 \pm \\
1.44 \pm\end{array}$ & \\
\hline
\end{tabular}

*Values are means $\pm S D$.

also measured on a continuous basis from the absorbance ratio at 560 and $576 \mathrm{~nm}$.

A first curve was drawn using the standard zero $(0$ per cent $\mathrm{O}_{2}: 5.6$ per cent $\mathrm{CO}_{2}: 94.4$ per cent $\mathrm{N}_{2}$ ) and span (25 per cent $\mathrm{O}_{2}: 5.6$ per cent $\mathrm{CO}_{2}: 69.4$ per cent $\mathrm{N}_{2}$ ) gases. A second curve was recorded with both zero and span gases containing 50 per cent $\mathrm{N}_{2} \mathrm{O}$ in addition to the standard $\mathrm{O}_{2}$ and $\mathrm{CO}_{2}$ content These four gas mixtures were especially prepared by Linde (Union Carbide), Oakville, Ont. Their $\mathrm{CO}_{2}$ content was checked (and found uniform) by equilibrating blood samples with the gases in a tonometer and reading the $\mathrm{PCO}_{2}$ with the $\mathrm{PCO}_{2}$ electrode of a blood gas analyzer (model ABL-1, Radiometer, Copenhagen).

In all cases, the temperature was maintained at $37^{\circ} \mathrm{C}$ and the $\mathrm{PCO}_{2}$ was kept at $5.32 \mathrm{kPa}$ $(40 \mathrm{mmHg})$. The acid-base status of each sample was established with an acid-base analyzer (model PHM7I, Radiometer, Copenhagen).

The $\mathrm{O}_{2}$ response of the Hem-O-Scan was checked by equilibrating the electrode in the instrument with gases of constant $\mathrm{PO}_{2}$. These were obtained by mixing the zero and the span gases with external flowmeters. The $\mathrm{O}_{2}$ concentration in the gas mixtures was continuously monitored with a paramagnetic analyzer (model E2, Beckman Instruments Inc., Palo Alto) and a Scholander gas analyzer. ${ }^{8}$ The Scholander technique was found unreliable with $\mathrm{N}_{2} \mathrm{O}$-containing mixtures.

The oxyhaemoglobin saturation given by the Hem-O-Scan was compared with the $\mathrm{O}_{2}$ saturation of an external blood sample which was equilibrated with the same gas mixture as the internal sample The $\mathrm{O}_{2}$ saturation of the external blood sample was calculated from its $\mathrm{Hb}$ content as measured by the Van Slyke manometric technique. ${ }^{9}$
The 2,3-DPG levels were measured by an ultraviolet enzymatic method (Sigma Chemical Co., Saint Louis) using a recording spectrophotometer (model SP 800, Pye Unicam Ltd, Cambridge).

\section{Results}

The preoperative $P_{50}$ was $26.4 \pm 1.0 \mathrm{mmHg}(3.5 \pm$ $0.1 \mathrm{kPa}$ ) (mean \pm S.D., $n=20$ ) as detemined from oxyhaemoglobin dissociation curves obtained using blood samples equilibrated with standard nitrous oxide-free gases (Table I). When 50 per cent $\mathrm{N}_{2} \mathrm{O}$ was present in the equilibrating gases, the $\mathbf{P}_{50}$ value for the same blood samples decreased to $18.4 \pm$ $1.4 \mathrm{mmHg}(2.4 \pm 0.2 \mathrm{kPa}$ ) (Fig. 1). Blood taken from the patients after $45-60$ minutes of $\mathrm{N}_{2} \mathrm{O}$ anaesthesia gave similar results. The $P_{50}$ was 25.9 \pm 1.5 and $18.3 \pm 1.6 \mathrm{mmHg}(3.4 \pm 0.2$ and $2.4 \pm$ $0.2 \mathrm{kPa}$ ) respectively when measured in the absence and presence of $\mathrm{N}_{2} \mathrm{O}$. In both series of samples the decrease in $\mathrm{P}_{50}$ due to $\mathrm{N}_{2} \mathrm{O}$ was highly significant (Student's t-test; $p<0.001$ ).

The shift of the $\mathrm{HbO}_{2}$ curve to the left was rapidly and completely reversible, and it could be induced or removed at will by switching $\mathrm{N}_{2} \mathrm{O}$-free and $\mathrm{N}_{2} \mathrm{O}$-containing gases.

All blood samples had normal acid-base characteristics. The $\mathrm{pH}$ was somewhat higher during operation $(7.43 \pm 0.07)$ than before $(7.37 \pm 0.03)$ and this was related to a decrease in $\mathrm{PCO}_{2}$ of about 5 $\mathrm{mmHg}$ as anesthetized patients were slightly hyperventilated (Table 1).

Since the Hem-O-Scan was imposing a constant $\mathrm{PCO}_{2}(40 \mathrm{mmHg}$ or $5.32 \mathrm{kPa})$ to all samples, $\mathrm{pH}$ and $\mathrm{PCO}_{2}$ should not have any systematic influence on the observed $P_{50}$. This assumption is supported by the normality of the $P_{50}$ measured in the absence of $\mathrm{N}_{2} \mathrm{O}$. It should equally apply to the $\mathrm{P}_{50}$ deter- 


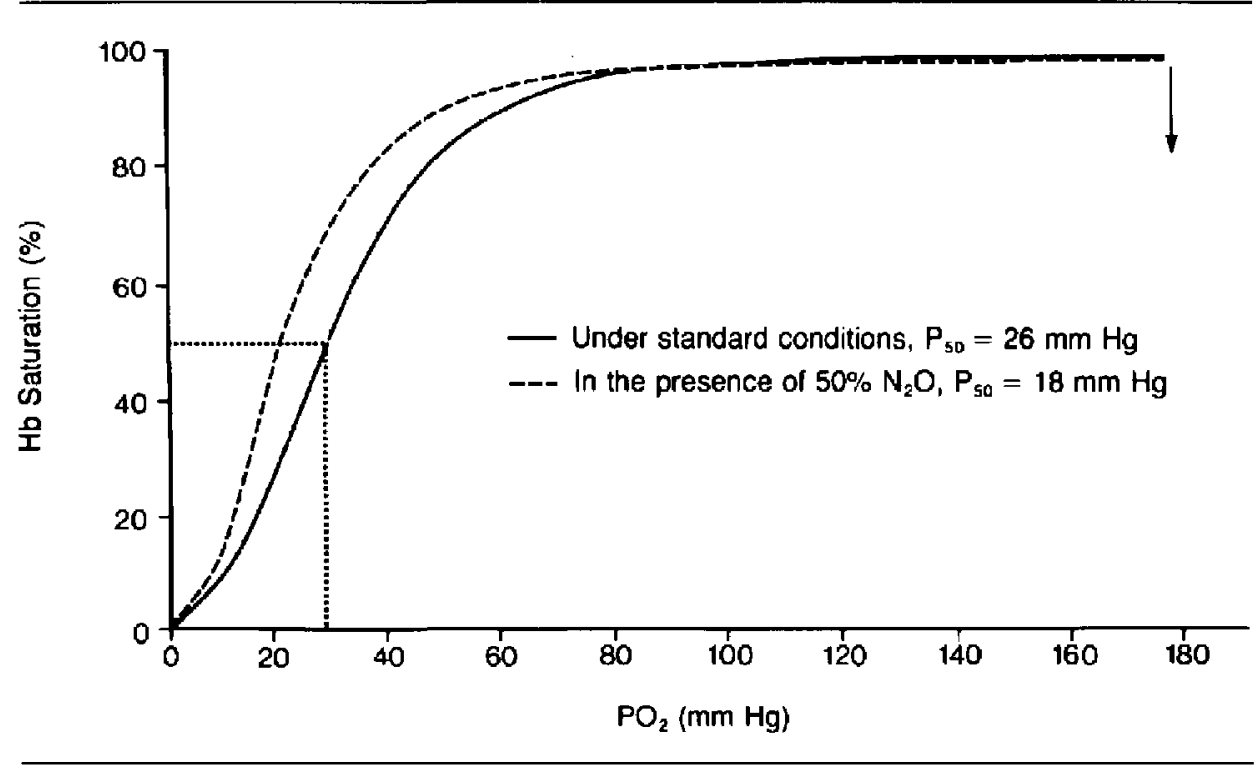

FIGURE 1 Typical haemoglobin dissociation curves obtained from same blood sample with the Hem-O-Scan.

mined in the presence of $\mathrm{N}_{2} \mathrm{O}$ since both $\mathrm{P}_{50}$ measurements were performed on the same sample and since $\mathrm{N}_{2} \mathrm{O}$ is not known to alter the acid-base status of the blood.

The concentration of 2,3-DPG in the preoperative blood samples was within normal limits (Table I). The intraoperative values were diminished by 13 per cent, but this decrease, although statistically significant (Student's t-test; $p<0.01$ ), appears too small to measurably affect the $P_{50}{ }^{10}$

The abserved decrease in the blood $\mathbf{P}_{50}$ could be explained by an error in $\mathrm{PO}_{2}$ measurement, an error in the determination of $\mathrm{HbO}_{2}$ saturation, both being due to $\mathrm{N}_{2} \mathrm{O}$, and/or by a reduced $\mathrm{O}_{2}$ affinity of $\mathrm{Hb}$ in the presence of $\mathrm{N}_{2} \mathrm{O}$.

Since $\mathrm{O}_{2}$ electrodes, especially those built with an $\mathrm{Au}$ cathode, were known to be sensitive to $\mathrm{N}_{2} \mathrm{O},{ }^{5,6}$ we conducted a careful check of the electrode which measures the $\mathrm{PO}_{2}$ in the Hem-OScan analyzer. In the absence of $\mathrm{N}_{2} \mathrm{O}$, determinations made with our electrode agreed perfectly with those made with both the Scholander and the paramagnetic analyzer. However, when calibrated with $\mathrm{N}_{2} \mathrm{O}$-free gases and used in the presence of $\mathrm{N}_{2} \mathrm{O}$, the electrode exhibited a strong background interference. For example, an $\mathrm{O}_{2}$-free gas containing 50 per cent $\mathrm{N}_{2} \mathrm{O}$ gave a reading equivalent to a $\mathrm{PO}_{2}$ of $30-50 \mathrm{mmHg}$. The zero control of the electrode did not allow such a high background value to be nulled and the starting point of most dissociation curves made in the presence of $\mathrm{N}_{2} \mathrm{O}$ was offset to the right by some $40 \mathrm{~mm}$. In spite of this offset, the $\mathrm{O}_{2}$ response of the electrode was found to be very linear between the zero and span gases and, once corrected with a simple equation, to agree closcly with paramagnetic determination. Figure 2 shows a typical calibration of the $\mathrm{O}_{2}$ electrode in the presence of $\mathrm{N}_{2} \mathrm{O}$. Each sample, however, was read from its own calibration curve drawn between the prevailing zero and span $\mathrm{PO}_{2}$.

The $\mathrm{HbO}_{2}$ saturation given by the Hem-O-Scan in the presence of $\mathrm{N}_{2} \mathrm{O}$ agreed with that measured by the Van Slyke technique as described in the Methods section. Furthermore the effect of 50 per cent $\mathrm{N}_{2} \mathrm{O}$ on the absorbance ratio $(560 / 576 \mathrm{~nm})$ used by the Hem-O-Scan to measure $\mathrm{HbO}_{2}$ was found to be negligible ( $<2$ per cent).

Since the shift of $\mathrm{HbO}_{2}$ dissociation curve to the left cannot be explained by the common affinity regulators or by methodological errors, we con- 


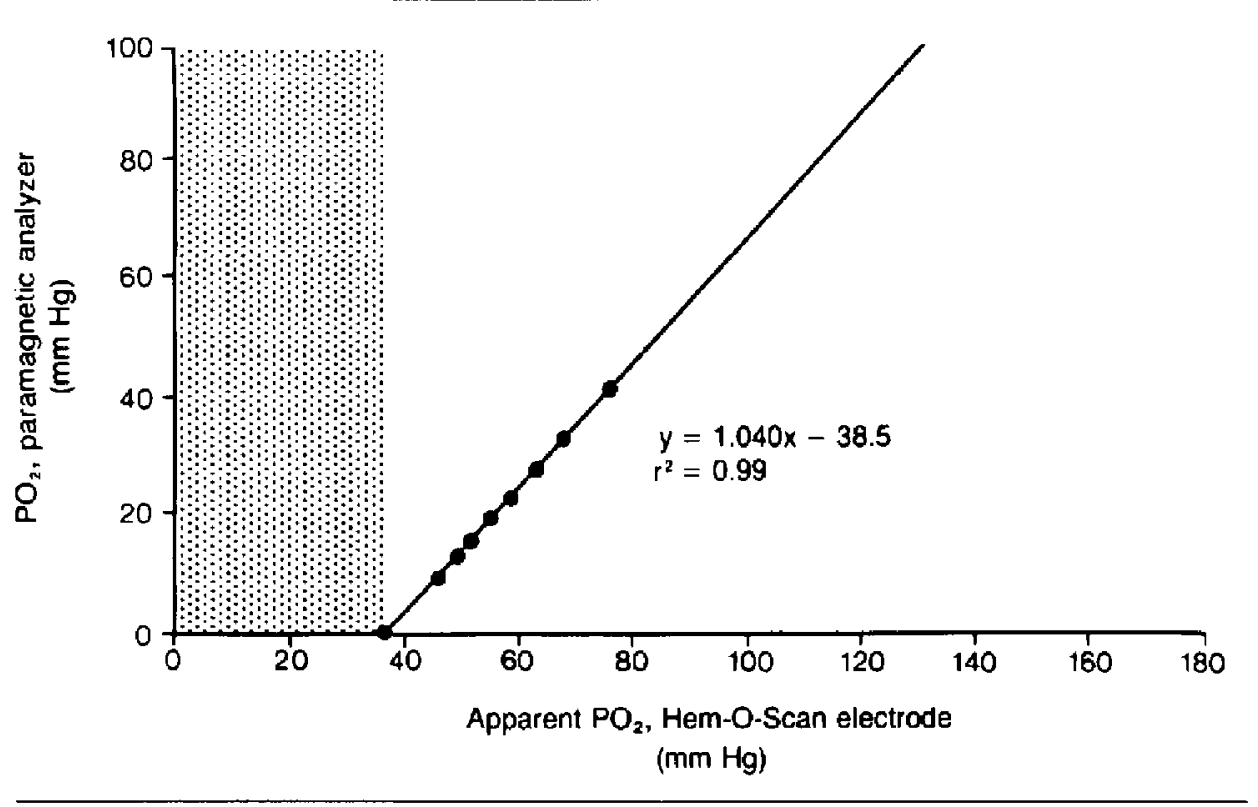

FIGURE 2 Typical calibration of the Hem-O-Scan $\mathrm{O}_{2}$ electrode in the presence of 50 per cent $\mathrm{N}_{2} \mathrm{O}$. Y-axis; paramagnetic analyzer readings. $X$-axis: uncorrected readings from the Hem-O-Scan scale. The matched area shows the magnitude of the background error on $\mathrm{PO}_{2}$.

clude that $\mathrm{N}_{2} \mathrm{O}$ increases the affinity of $\mathrm{Hb}$ for oxygen and thus reduces the $\mathrm{O}_{2}$ available to the tissues.

\section{Discussion}

Our data indicate that exposure of a blood sample to $\mathrm{N}_{2} \mathrm{O}$ causes a leftward shift of the oxyhaemoglobin dissociation curve. This shift, which reduces the $\mathrm{P}_{50}$ by $1.06 \mathrm{kPa}(8 \mathrm{mmHg})$ in the presence of 50 per cent $\mathrm{N}_{2} \mathrm{O}$ cannot be explained by temperature, $\mathrm{pH}$, $\mathrm{PCO}_{2}$ or 2,3-DPG effects. The normal $\mathrm{O}_{2}$ affinity of $\mathrm{Hb}$ is rapidly restored whenever the blood is exposed to $\mathrm{N}_{2} \mathrm{O}$-free gas.

Our results are at variance with those previously published by Prime in 1951, ' ' who found no effect of $\mathrm{N}_{2} \mathrm{O}\left(\mathrm{FN}_{2} \mathrm{O}=0.70\right)$ on the haemoglobin dissociation curve, leaving the $\mathrm{P}_{50}$ in the $24-25 \mathrm{mmHg}$ range. In addition to the possibility that the blood from the single subject investigated by Prime may have been atypical, methodological differences can contribute to the discrepancy between his results and ours. Since both his and our studies rely on the Van Slyke analysis as the primary measurement of the hacmoglobin saturation, the variance is likely to stem from the $\mathrm{PO}_{2}$ determination. Either he overestimated the $\mathrm{PO}_{2}$ or we underestimated it. In order to analyze his experimental gases, Prime used a modified Haldane apparatus. He carefully showed that $\mathrm{N}_{2} \mathrm{O}$ was not absorbed by the $\mathrm{O}_{2}$-trapping reagent. ${ }^{12}$ However, he apparently did not, as we did with the paramagnetic analysis, specifically check for the accuracy of $\mathrm{O}_{2}$ determination by an independent method having a low sensitivity to $\mathrm{N}_{2} \mathrm{O}$. For these reasons, we think that our results may be more accurate.

Our results are also in disagreement with those reported by Smith ef al. in $1970 .^{7}$ These authors concluded that $\mathrm{N}_{2} \mathrm{O}$ (at unspecified concentration) was responsible for a right shift of the oxyhaemoglobin dissociation curve, resulting in a $0.36 \mathrm{kPa}$ (2.7 $\mathrm{mmHg}$ ) increase of the $\mathrm{P}_{50}$. Again, the discrepancy between their results and ours may arise from a difference in the determination of $\mathrm{PO}_{2}$ Although Smith et al. also used $\mathrm{O}_{2}$ electrodes, they were likely to neglect the positive interference of $\mathrm{N}_{2} \mathrm{O}$ on polarographic measurements of $\mathrm{O}_{2}$, since it 
was unreported at that time. This interference will lead to an overestimation of the $\mathrm{PO}_{2}$ and thus of the $\mathrm{P}_{50}$. When measuring an oxyhaemoglobin dissociation curve, overestimating the $\mathrm{PO}_{2}$ can possibly transform a left shift into a right shift.

The issue discussed above is more than academic. When using $\mathrm{N}_{2} \mathrm{O}$ anaesthesia, ignorance of a significant decrease in the $\mathrm{P}_{50}$, combined with a possible overestimation of $\mathrm{PO}_{2}$ due to $\mathrm{N}_{2} \mathrm{O}$ effect on $\mathrm{O}_{2}$ electrodes may have dire consequences in certain of our borderline patients. The oxygen available to their tissues would be much lower than what we estimate from the measured $\mathrm{PO}_{2}$ which is our guideline for a good oxygenation of our patients.

\section{Acknowledgements}

The authors thank Dr. Jacques Larochelle, D.Sc. for his important collaboration during this work, the anesthesiologists from the CHUL for their helpful professional participation and Mrs. Angeline Lafontaine for her technical assistance.

\section{References}

1 Nurn JF, Chanarin J. Nitrous oxide and vitamin B $_{12}$. Br J Anaesth 1978; 50: 1089-90.

2 Wyane J, Mann T, Alpert JS, Green LH, Grossmon $W$. Hemodynamic effects of nitrous oxide administered during cardiac catheterization. JAMA 1980; 243: 1440-3.

$3 \mathrm{Ngai}$ SH. Finck $A D$. Prolonged exposure to nitrous oxide decreases opiate receptor density in rat brainstem. Anesthesiology 1982;57: 26-30.

4 Artru AA. Nitrous oxide plays a direct role in the development of tension pneumocephalus intraoperatively. Anesthesiology 1982; 57:59-61.

5 Evans MC, Cameron IR. Oxygen electrodes sensitive to nitrous oxide. Lancet 1978; 2(8104-5): 1371 .

6 Alberry WJ, Brooks WN, Gibson SP, Hahn CEW. An electrode for $\mathrm{PN}_{2} \mathrm{O}$ and $\mathrm{PO}_{2}$ analysis in bload and gas. J Appl Physiol 1978; 45: 637-43.

7 Smith TC, Colton ET, Behar MG. Does ancsthesia alter hemoglobin dissociation? Anesthesiology 1970; 32: 5-12.

8 Scholander PF. Analyzer for accurate estimation of respiratory gases in one-half cubic centimeter samples. I Biol Chem 1947; 167: 235-50.

9 Oser BL (editor). Hawk's physiological chemistry. New York: McGraw-Hill Book Co., 1965.
10 Oak FA, Gotlieb AJ, Miller WW, DelivoriaPapapoulos $M$. The effects of deoxygenation of adult and fetal hemoglobin on the synthesis of red cell 2,3-diphosphoglycerate and its in vivo consequences. J Clin Invest 1970; 49: 400

11 Prime FJ. Oxygen dissociation curves of whole blood in the presence of anaesthetic gases. $\mathrm{Br} \mathrm{J}$ Anacsth 1951; 23: 171-9.

12 Prime FJ. Volumetric determination of ether or cyclopropane, carbon dioxide, nitrous oxide and oxygen in anaesthetic mixturcs. Br J Anaesth 1950; 22: $162-70$

Résumé

Nous avons observé, à partir de courbes de dissociation de l'axyhémoglobine ( $C D O$ ), que le prosoxyde d'azote $\left(\mathrm{N}_{2} \mathrm{O}\right)$ augmente l'affinilé de l'hémoglobine pour l'oxygène. L'exposition d'échantillons de sang prélevé chez vingt sujets normaux (risque anesthésique ASA-J) d un mélange de gaz contenant 50 pour cent $\mathrm{N}_{2} \mathrm{O}$ déplace la CDO vers la gauche, entrainant une baisse de la $P_{50}$ de $3.46 \mathrm{kPa}(26 \mathrm{mmHg} / a 2.39 \mathrm{kPa}(18 \mathrm{~mm} / \mathrm{g})$. Cette baisse n'a pu être expliquée par des effets de température, de $\mathrm{PCO}_{2}$, de pH ou de 2,3-DPG. L'effet du $\mathrm{N}_{2} \mathrm{O}$ est toutefois réversible et disparait rapidement en exposant par la suite les échantillons de sang à des mélanges gazeux sans $\mathrm{N}_{2} \mathrm{O}$, Ces observations contredisent les publications antérieures qui concluaient que le protoxyde avait peu d'influence sur la $P_{50}$. Notre propre conclusion est que les influences du protoxyde sur la courbe de dissociation de t'oxyhémoglobine et sur les lectures de la $\mathrm{PO}_{2}$ peuvent avoir des conséquences néfastes chez les patients d̀ risque élevé. 